\title{
Electrospray tandem mass spectrometric analysis of a dimeric conjugate, salvialeriafone and related compounds
}

\author{
Syed Ghulam Musharraf ${ }^{1 *}$, Madiha Goher ${ }^{1}$, Amjad Hussain $^{1}$ and M lqbal Choudhary ${ }^{1,2}$
}

\begin{abstract}
Background: Electrospray tandem mass spectrometry approach is widely used for the rapid characterization of natural products. This paper describes the gas-phased ESI-MS/MS fragmentation of abietane-type diterpenoids and their novel dimeric conjugate, salvialeriafone (1) using both positive and negative ion electrospray ionization quadropole time-of-flight mass spectrometry (ESI-QqTOF-MS/MS) hybrid instrument. Diterpenoids are widely distributed throughout the plant kingdom and posses interesting biological activities.

Results: ESI-QqTOF-MS (positive ion mode) of diterpenoids 1-6 under collision-induced dissociation tandem mass spectrometric analysis (CID-MS/MS) showed the characteristic losses of water, carbonmonoxide and propene molecules, while analysis in negative ion mode showed the characteristic losses of water, carbon monoxide, methane molecules and methyl radical. Results demonstrated the differences in the product ions and base peaks due to the differences in the skeleton. A novel dimeric conjugate, salvialeriafone (1) showed characteristic fragmentation pattern and was found to be more prone to form radical ions, as compared to monomeric diterpenoids. The fragmentation pathways of characteristic fragments were proposed with the aid of HRESIMS.

Conclusions: Extensive tandem mass spectrometric studies of salvialeriafone (1) and related diterpenoids 2-6 were conducted and their characteristic fragments were identified. The knowledge of the fragmentation pattern of these diterpenoids will be useful for the characterization of new dimers of this class of compounds.
\end{abstract}

Keywords: Abietane diterpenoids, Tandem mass spectrometry, Salvia leriaefolia, ESI-QqTOF-MS, Salvialeriafone

\section{Introduction}

Diterpenoids constitute a large class of chemically diverse metabolites, widely distributed throughout the plant kingdom with more than 12,000 known examples [1]. Most of the diterpenoids posses diverse biological properties, such as antitumor [2], cytotoxic, antibacterial [3], antiplasmodial [4], leishmanicidal, gastroprotection, molluscicidal [5], antifungal [6], insecticidal [7], rodenticidal [8] and antiproliferative activities. Some of them have effects on cardiovascular and central nervous systems [9].

The genus Salvia constitutes the largest of the plant family Labiatea with 900 species wide-spread throughout

\footnotetext{
* Correspondence: musharraf1977@yahoo.com

'H.E.J. Research Institute of Chemistry, International Center for Chemical and Biological Sciences, University of Karachi, Karachi 75270, Pakistan

Full list of author information is available at the end of the article
}

the world. The genus has yielded various classes of natural products, including the major class of terpenoids, particularly the diterpenoids. Diterpenoids of genus Salvia are abietane and neo-clerodane types [10]. More than 400 diterpenoids with different abietane skeletons have been isolated from Salvia plants [11]. Diterpenoids from Salvia species showed antinflammatory, antidiabetic, ipolipidemic and antiaggregating effects [9]. We have recently isolated salvialeriafone, a dimeric conjugate from Salvia leriaefolia which exhibit in vitro antiproliferative activity against the human cervical cancer cell line (Hela) [12]. S. leriaefolia is used for the treatment of stomach and chronic disorders in Iran.

Many analytical methods including thin-layer chromatography (TLC) [13], high-performance liquid chromatography (HPLC) [14-17] and liquid chromatography-mass spectrometry (LC-MS). [11,18-21] have been used for the analysis of chemical constituents of Salvia plants.
(C) Chemistry Central

C 2012 Musharraf et al.; licensee Chemistry Central Ltd. This is an Open Access article distributed under the terms of the Creative Commons Attribution License (http://creativecommons.org/licenses/by/2.0), which permits unrestricted use, distribution, and reproduction in any medium, provided the original work is properly cited. 
Tandem mass spectrometric studies of natural products revealed the identification of key fragments which can be helpful for their rapid characterization in the plant extract utilizing LC-MS/MS approach, particularly for the thermally labile compounds. The knowledge of CID-fragmentation pattern of the precursor protonated (or deprotonated) molecule is essentially required prior to the analysis quantification of the desired compounds by LC-MS/MS.

In continuation of our research on the novel characterization and the fragmentation routes of natural product compounds [22-24], we report in this manuscript for the first time the ESI-MS and CID-MS/MS ( + and - modes) of salvialeriafone and its related abietane diterpenoids isolated from S. leriaefolia. Knowledge about the characteristic fragments and neutral losses of diterpenoids can be immensely helpful for the rapid identification of these compounds in future phytochemical studies.

\section{Material and methods}

\section{Standard and reagents}

Chemicals and solvents were of analytical and HPLC grades, respectively, and were purchased from AldrichSigma (USA). Deionized water (Milli-Q) was used in the study. Standard diterpenoids were obtained from the Molecular Bank facility at the Dr. Panjwani Center for Molecular Medicine and Drug Research (International Center for Chemical and Biological Sciences), University of Karachi. The isolation procedure and spectroscopic data of the standard diterpenoids has already been reported [12].

\section{ESI-QqTOF-MS analysis}

\section{Positive ion mode}

The diterpenoids were dissolved in methanol, and working dilution was prepared in 1:1 acetonitrile-water containing $0.1 \%$ trifluoroacetic acid and analyzed by electrospray ionization (ESI) and collision-induced dissociation (CID),

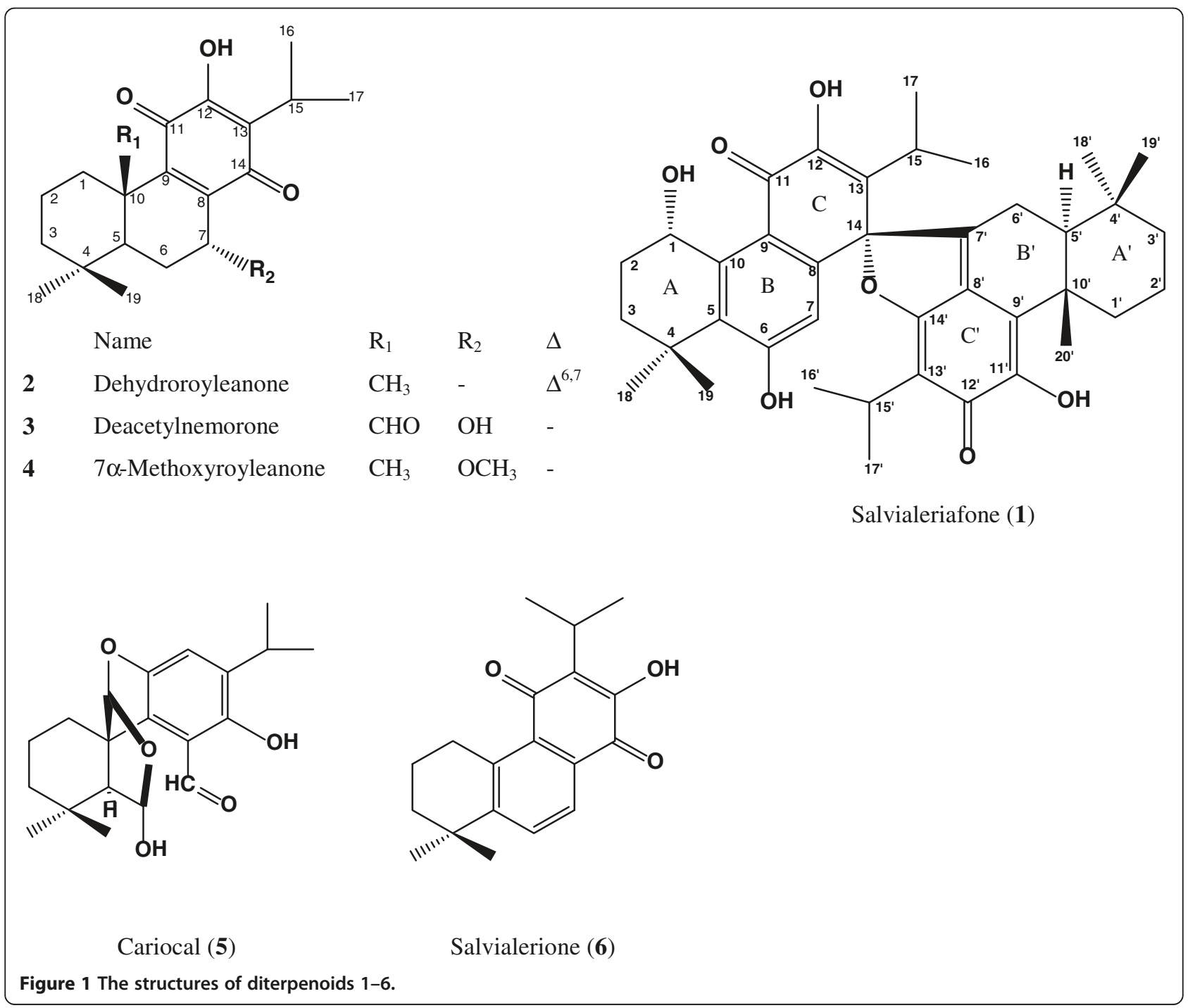


positive ion mode, on QqTOF-MS/MS instrument (QSTAR XL mass spectrometer Applied Biosystem/ MDS Sciex, Darmstadt, Germany) at room temperature. Highpurity nitrogen gas was used as the curtain gas and collision gas delivered from Peak Scientific nitrogen generator. The ESI interface conditions were as follows: ion spray capillary voltage of $5500 \mathrm{~V}$, curtain gas flow rate $20 \mathrm{~L} \mathrm{~min}^{-1}$, nebulizer gas flow rate $30 \mathrm{~L} \mathrm{~min}^{-1}$, DP1 $60 \mathrm{~V}, \mathrm{DP} 215 \mathrm{~V}$, and focusing potential of $265 \mathrm{~V}$. The collision energy was swept from 05 to $45 \mathrm{eV}$ for MS/MS analysis. Calibration was performed by using internal calibration process. Sample was introduced into the mass spectrometer using a Harvard syringe pump (Holliston, MA) at a flow rate of $5 \mu \mathrm{L} / \mathrm{min}$. MS ${ }^{2}$ Experiment was conducted by selecting the product ion.

\section{Negative ion mode}

The diterpenoids were dissolved in methanol and working dilutions were prepared in 1:1 acetonitrile-water containing $4 \mathrm{mM}$ ammonium acetate $(0.2 \mathrm{ng} / \mathrm{uL}$ taurochloric acid was used as an internal calibrant) and analyzed by electrospray ionization (ESI) and collision-induced dissociation (CID) negative ion mode on QqTOF-MS/MS instrument (QSTAR XL mass spectrometer Applied Biosystem/ MDS
Sciex, Darmstadt, Germany) at room temperature. Highpurity nitrogen gas was used as the curtain gas and collision gas delivered from Peak Scientific nitrogen generator. The ESI interface conditions were as follows: ion spray capillary voltage of $-4200 \mathrm{~V}$, curtain gas flow rate $20 \mathrm{~L}$ $\mathrm{min}^{-1}$, nebulizer gas flow rate $25 \mathrm{~L} \mathrm{~min}{ }^{-1}$, DP1 $-55 \mathrm{~V}$, DP2 $-15 \mathrm{~V}$, and focusing potential of $-265 \mathrm{~V}$. The collision energy was swept from 20 to $55 \mathrm{eV}$ for MS/MS analysis. Calibration was performed using internal calibration process. Sample was introduced into the mass spectrometer using a Harvard syringe pump (Holliston, MA) at a flow rate of $5 \mu \mathrm{L} / \mathrm{min}$. $\mathrm{MS}^{2}$ Experiment was conducted by selecting the product ion.

\section{Results and discussion}

Salvialeriafone (1), along with other diterpenoids 2-6 (Figure 1), were investigated by the positive and negative ESI-QqTOF-MS analysis. Fragmentation pattern and the product ion abundance were found to be significantly influenced by the variation of collision energy. Therefore MS/MS spectra of all compounds were screened against collision energies, ranging between 20 to $55 \mathrm{eV}$ (with stepping up of $5 \mathrm{eV}$ each time). Relative intensities of product ions of $[\mathrm{M}+\mathrm{H}]^{+}$and $[\mathrm{M}-\mathrm{H}]^{-}$versus collision
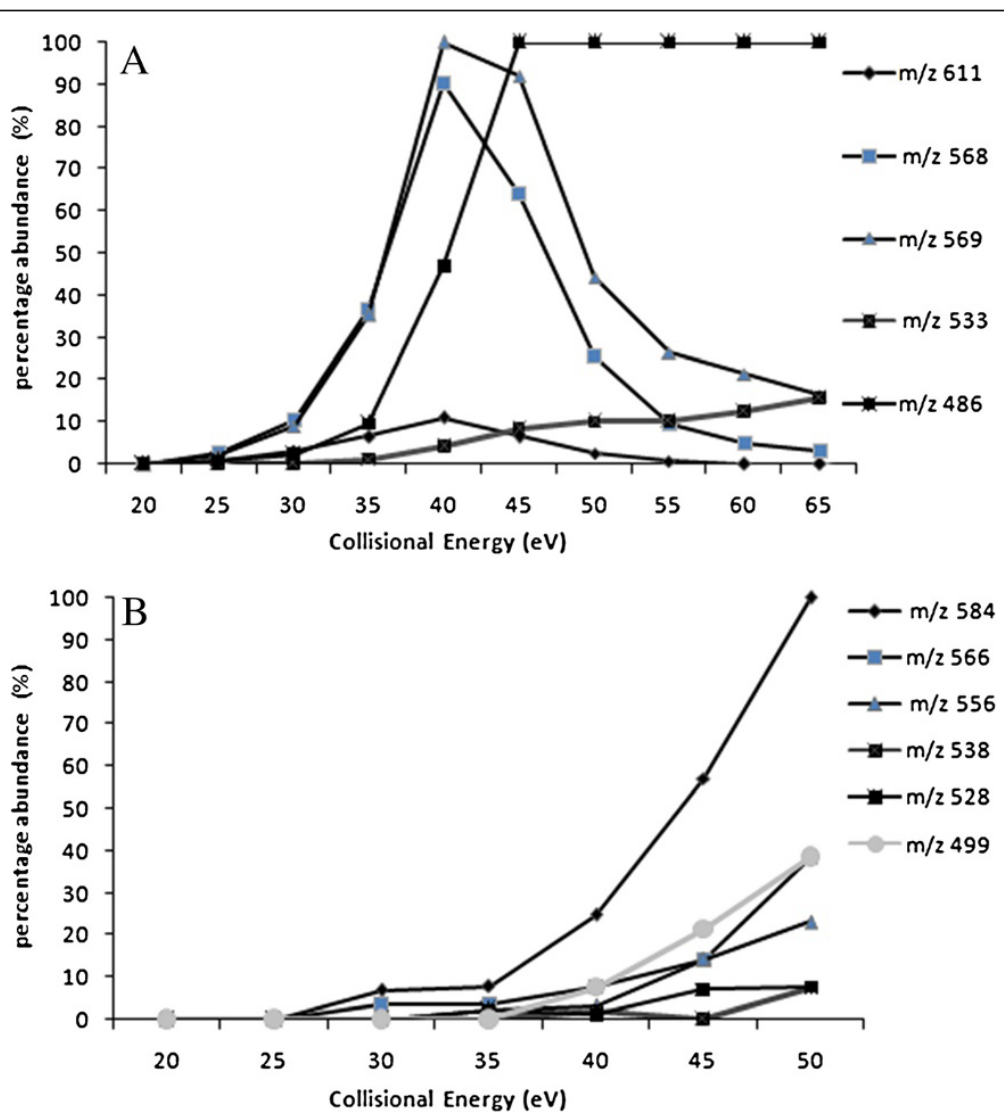

Figure 2 Relative intensity of product ions versus collision energy in the product ion spectra of compound $1 \mathrm{~A}$. in positive ion mode, B. in negative ion mode. 
Table 1 Positive ionization HR-ESI-MS data and common neutral losses of diterpenoids 1-6

\begin{tabular}{|c|c|c|c|c|c|c|c|c|c|c|c|c|c|}
\hline S.No. & {$[\mathrm{M}+\mathrm{H}]^{+}$} & $\begin{array}{l}\text { Exact } \\
\text { Mass }\end{array}$ & $\begin{array}{l}\text { Observed } \\
\text { mass }\end{array}$ & $\begin{array}{l}\text { Error } \\
\text { (ppm) }\end{array}$ & {$\left[\mathrm{M}+\mathrm{H}-\mathrm{H}_{2} \mathrm{O}\right]^{+}$} & {$[\mathrm{M}+\mathrm{H}-\mathrm{CO}]^{+}$} & {$\left[\mathrm{M}+\mathrm{H}-\mathrm{C}_{3} \mathrm{H}_{6}\right]^{+}$} & {$\left[\mathrm{M}+\mathrm{H}-2 \mathrm{H}_{2} \mathrm{O}\right]^{+}$} & $\begin{array}{l}{[\mathrm{M}+\mathrm{H}-} \\
\left.\mathrm{C}_{3} \mathrm{H}_{7}\right]^{+}\end{array}$ & $\begin{array}{c}{\left[\mathrm{M}+\mathrm{H}-\mathrm{C}_{3} \mathrm{H}_{6}-\right.} \\
\left.\mathrm{H}_{2} \mathrm{O}\right]^{+}\end{array}$ & $\begin{array}{c}{[\mathrm{M}+\mathrm{H}-} \\
\mathrm{H}_{2} \mathrm{O}-\mathrm{CO}^{+}\end{array}$ & $\begin{array}{c}{\left[\mathrm{M}+\mathrm{H}-\mathrm{C}_{3} \mathrm{H}_{6}-\right.} \\
\mathrm{H}_{2} \mathrm{O}-\mathrm{CO}^{+}\end{array}$ & Base Peak \\
\hline 1 & $\mathrm{C}_{39} \mathrm{H}_{49} \mathrm{O}_{7}^{+}$ & 629.3472 & 629.3444 & -4.58 & 611 & - & 569 & - & $\begin{array}{c}568 \\
{[\mathrm{M}+\mathrm{H}-} \\
\left.\mathrm{H}_{2} \mathrm{O}-\mathrm{C}_{3} \mathrm{H}_{7}\right]^{+}\end{array}$ & 569 & - & - & $\begin{array}{c}569 \\
{\left[\mathrm{M}+\mathrm{H}-\mathrm{C}_{3} \mathrm{H}_{6^{-}}\right.} \\
\left.\mathrm{H}_{2} \mathrm{O}\right]^{+}\end{array}$ \\
\hline 2 & $\mathrm{C}_{20} \mathrm{H}_{27} \mathrm{O}_{3}^{+}$ & 315.1965 & 315.1983 & 5.49 & 297 & - & 273 & - & 272 & 255 & 269 & 227 & $\begin{array}{c}245 \\
{\left[\mathrm{M}+\mathrm{H}-\mathrm{C}_{3} \mathrm{H}_{6}-\mathrm{C}_{2} \mathrm{H}_{4}\right]^{+}}\end{array}$ \\
\hline 3 & $\mathrm{C}_{20} \mathrm{H}_{27} \mathrm{O}_{5}^{+}$ & 347.1863 & 347.1871 & 2.02 & 329 & 319 & - & 311 & - & - & 301 & 255 & $\begin{array}{c}283 \\
{\left[\mathrm{M}+\mathrm{H}-2 \mathrm{H}_{2} \mathrm{O}-\mathrm{CO}\right]^{+}}\end{array}$ \\
\hline 4 & $\mathrm{C}_{21} \mathrm{H}_{31} \mathrm{O}_{4}^{+}$ & 347.2227 & 347.2226 & -0.53 & $\begin{array}{c}315 \\
{[\mathrm{M}+\mathrm{H}-} \\
\left.\mathrm{CH}_{3} \mathrm{OH}\right]^{+}\end{array}$ & - & - & - & - & $\begin{array}{c}297 \\
{[\mathrm{M}+\mathrm{H}-} \\
\left.\mathrm{CH}_{3} \mathrm{OH}-\mathrm{H}_{2} \mathrm{O}\right]^{+}\end{array}$ & $\begin{array}{c}255 \\
{[\mathrm{M}+\mathrm{H}-} \\
\mathrm{CH}_{3} \mathrm{OH}-\mathrm{H}_{2} \mathrm{O}- \\
\left.\mathrm{C}_{3} \mathrm{H}_{6}\right]^{+}\end{array}$ & $\begin{array}{c}269 \\
{[\mathrm{M}+\mathrm{H}-} \\
\mathrm{CH}_{3} \mathrm{OH}- \\
\left.\mathrm{H}_{2} \mathrm{O}-\mathrm{CO}\right]^{+}\end{array}$ & $\begin{array}{c}269 \\
{[\mathrm{M}+\mathrm{H}-} \\
\left.\mathrm{CH}_{3} \mathrm{OH}-\mathrm{H}_{2} \mathrm{O}-\mathrm{CO}\right]^{+}\end{array}$ \\
\hline 5 & $\mathrm{C}_{20} \mathrm{H}_{27} \mathrm{O}_{5}^{+}$ & 347.1863 & 347.1862 & -0.57 & 329 & - & & 311 & - & - & 301 & 259 & $\begin{array}{c}281 \\
{\left[\mathrm{M}+\mathrm{H}-2 \mathrm{H}_{2} \mathrm{O}-\mathrm{CH}_{2} \mathrm{O}\right]^{+}}\end{array}$ \\
\hline 6 & $\mathrm{C}_{19} \mathrm{H}_{23} \mathrm{O}_{3}^{+}$ & 299.1641 & 299.1674 & 10.79 & 281 & - & - & - & 256 & 239 & 253 & 211 & $\begin{array}{c}256 \\
{[\mathrm{M}+\mathrm{H}-} \\
\left.\mathrm{C}_{3} \mathrm{H}_{7}\right]^{+}\end{array}$ \\
\hline
\end{tabular}


energy ranging were plotted for salvialeriafone (1) (Figure 2). It was observed that the product ions formation was at best at collision energy $40 \mathrm{eV}$ (Figure 2A) in positive ion mode, whereas in negative ionization mode the product ions were best formed at the optimum energy collision energy $50 \mathrm{eV}$ (Figure 2B).

\section{Fragmentation pattern in positive ionization}

All diterpenoids produced abundant $[\mathrm{M}+\mathrm{H}]^{+}$ions which were selected as the precursor ions to produce MS/MS spectra, but the $[\mathrm{M}+\mathrm{H}]^{+}$ion is absent in the MS spectra of compound $\mathbf{5}$ which gives the dehydrated peak $[\mathrm{M}+\mathrm{H}-$ $\left.\mathrm{H}_{2} \mathrm{O}\right]^{+}$, therefore this ion was selected as a precursor ion to produce MS/MS spectra of compound 5. HRESIMS data of all compounds in positive ion mode is presented in Table 1. All the compounds showed similar fragmentation pattern with minor differences and similar losses of $\mathrm{H}_{2} \mathrm{O}, \mathrm{CO}, \mathrm{C}_{3} \mathrm{H}_{6}$ (Table 1), but the extent of fragmentation and optimium collision energy vary due to different substituents and presence of double bonds in the ring. All these diterpenoid 2-6 showed intense fragmentation and neutral losses, while compound $\mathbf{1}$ which is a conjugate of two diterpenoids showed very low fragmentation even at high collision energy. It showed the loss of propene after the water removal as a base peak, i.e. $\left[\mathrm{M}+\mathrm{H}-\mathrm{H}_{2} \mathrm{O}-\mathrm{C}_{3} \mathrm{H}_{6}\right]^{+}$at $m / z 569.2839\left(\mathrm{C}_{36} \mathrm{H}_{41} \mathrm{O}_{6}^{+}\right.$, calc. 569.2897). The other ions were produced at $\mathrm{m} / \mathrm{z}$ 568.2786 (calc. 568.2819) $\left[\mathrm{M}+\mathrm{H}-\mathrm{H}_{2} \mathrm{O}-\mathrm{C}_{3} \mathrm{H}_{7}\right]^{+}, 611.3297$ (calc. 611.3367) $\left[\mathrm{M}+\mathrm{H}-\mathrm{H}_{2} \mathrm{O}\right]^{+}, 553.2412$ (calc. 553.2584) $\left[\mathrm{M}+\mathrm{H}-\mathrm{C}_{3} \mathrm{H}_{6}-\mathrm{CH}_{4}\right]^{+}$. Fragments due to the loss of $\mathrm{CO}$ and other consequent lossess did not appear in the MS/ MS spectra of compound 1 (Figure 3A).

The fragmentation pattern of momeric diterpenoids 2-6 were studied in order to further validate the neutral lossess and fragmentation pattern of the dimeric conjugate, salvialeriafone (1). All diterpenoids showed the removal of water molecule, i.e. $\left[\mathrm{M}+\mathrm{H}-\mathrm{H}_{2} \mathrm{O}\right]^{+}$except compound 4 which showed the removal of methanol due to the presence of methoxy group followed by the loss of water molecule. A loss of water molecule followed by the loss of $\mathrm{CO}$ was observed in compounds 2 , $\mathbf{3}, \mathbf{5}$, and $\mathbf{6}$, while compounds having $\mathrm{OH}$ group in ring $\mathrm{B}$ (compounds 3 and 5) showed the loss of two water molecules, i.e. $\left[\mathrm{M}+\mathrm{H}-2 \mathrm{H}_{2} \mathrm{O}\right]^{+}$. All analyzed compounds
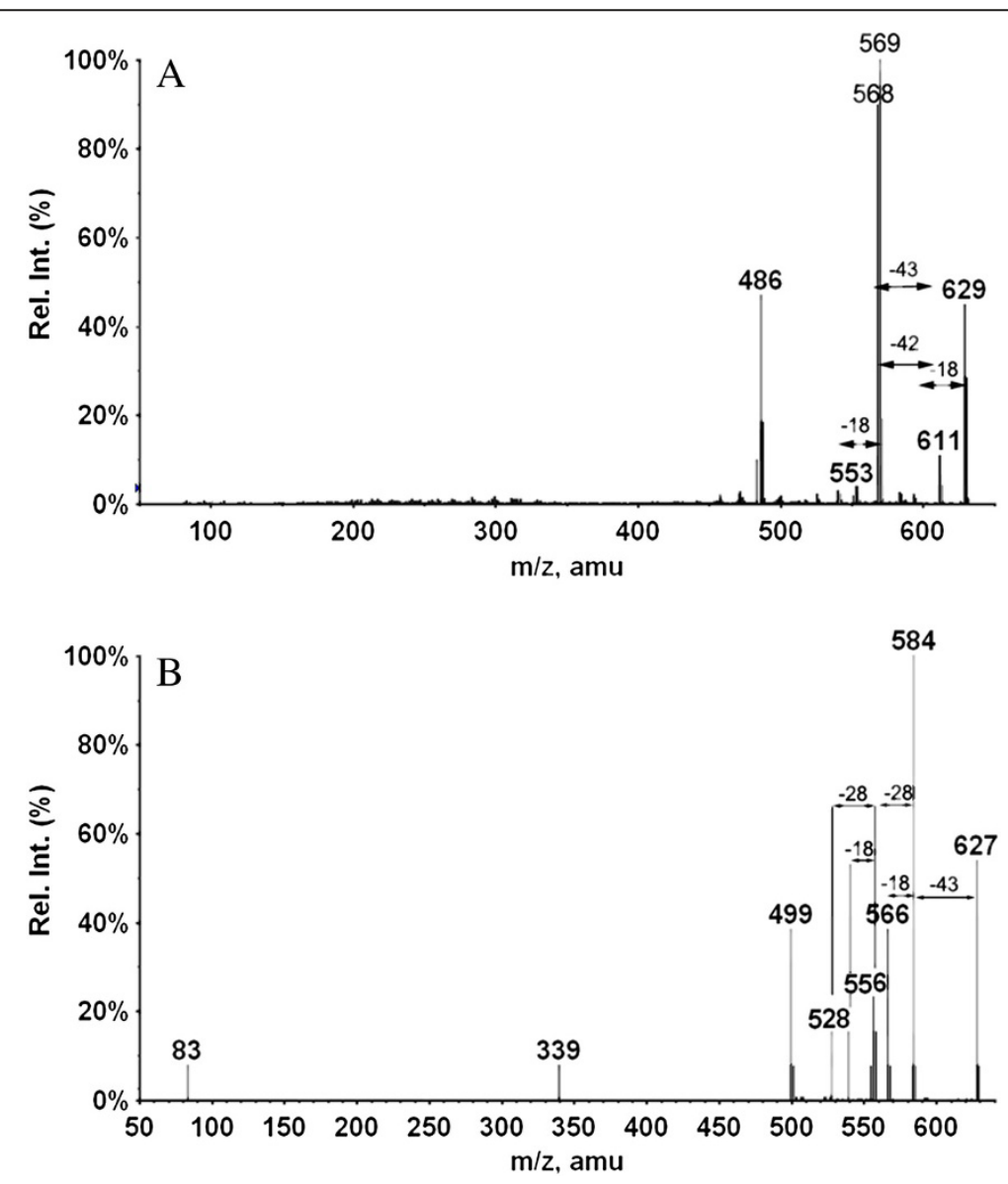

Figure 3 Product ion spectra of Salvialeriafone (1), A. recorded on positive ion mode at collision enegy $40 \mathrm{eV}$, B. recorded on negative ion mode at collision energy $50 \mathrm{eV}$. 
showed the removal of propene moiety directly from the $[\mathrm{M}+\mathrm{H}]^{+}$and/or after the removal of $\mathrm{H}_{2} \mathrm{O}$ and $\mathrm{CO}$ groups. These compounds also showed the neutral lossess of ethene and butane molecules. Compounds $\mathbf{3}$ and 5 having same molecular formula but difference of skeleton in ring $\mathrm{B}$ produced differentiated base peak and some other abundant peaks (Table 1). Compound 3 showed the base peak at $\mathrm{m} / z 283\left[\mathrm{M}+\mathrm{H}-2 \mathrm{H}_{2} \mathrm{O}-\mathrm{CO}\right]^{+}$, while compound $\mathbf{5}$ showed the base peak at $\mathrm{m} / \mathrm{z} 281$ $\left[\mathrm{M}+\mathrm{H}-2 \mathrm{H}_{2} \mathrm{O}-\mathrm{CH}_{2} \mathrm{O}\right]^{+}$and compound $\mathbf{5}$ also showed the intense fragments at $m / z 217$ and 205, while the peak at $\mathrm{m} / z 319[\mathrm{M}+\mathrm{H}-\mathrm{CO}]^{+}$is absent in compound 5. Like compound 1, compounds $\mathbf{2}$ and $\mathbf{6}$ also showed the presence of abundant peaks of radical cations due to the loss of propyl radical. Unlike monomeric diterpenoids the product ion spectra of compound $\mathbf{1}$ was very simple, having only a few peaks in the range of $\geq m / z 486$. However, being a dimer, compound $\mathbf{1}$ possess two isopropyl and four hydroxyl substituents, but showed the loss of substituents equivalent to the loss which are derived from a monomeric diterpenoid unit. Fragmentation pathway for the fragments formed due to the removal of $\mathrm{CO}$, $\mathrm{C}_{3} \mathrm{H}_{6}$, and $\mathrm{H}_{2} \mathrm{O}$ has also proposed as and shown in Scheme 1 (compound $\mathbf{2}$ is taken as a representive of monomeric diterpenoids).

\section{Fragmentation pattern in negative ionization}

All diterpenoids 1-6 produced abundant $[\mathrm{M}-\mathrm{H}]^{-}$ions, which were selected as the precursor ions to produce MS/MS spectra. The QTOF-MS/MS the low-energy collision induced dissociation tandem mass spectrometry experiments (CID-MS/MS) were optimized and developed through ramping collision voltage to induce more product ions and the optimum collision energy for recording product ion spectra of diterpenoids in negative ion mode is ranging from 30 to $45 \mathrm{eV}$ HRESIMS data of all compounds in negative ion mode is presented in Table 2. In negative ion mode, all the compounds

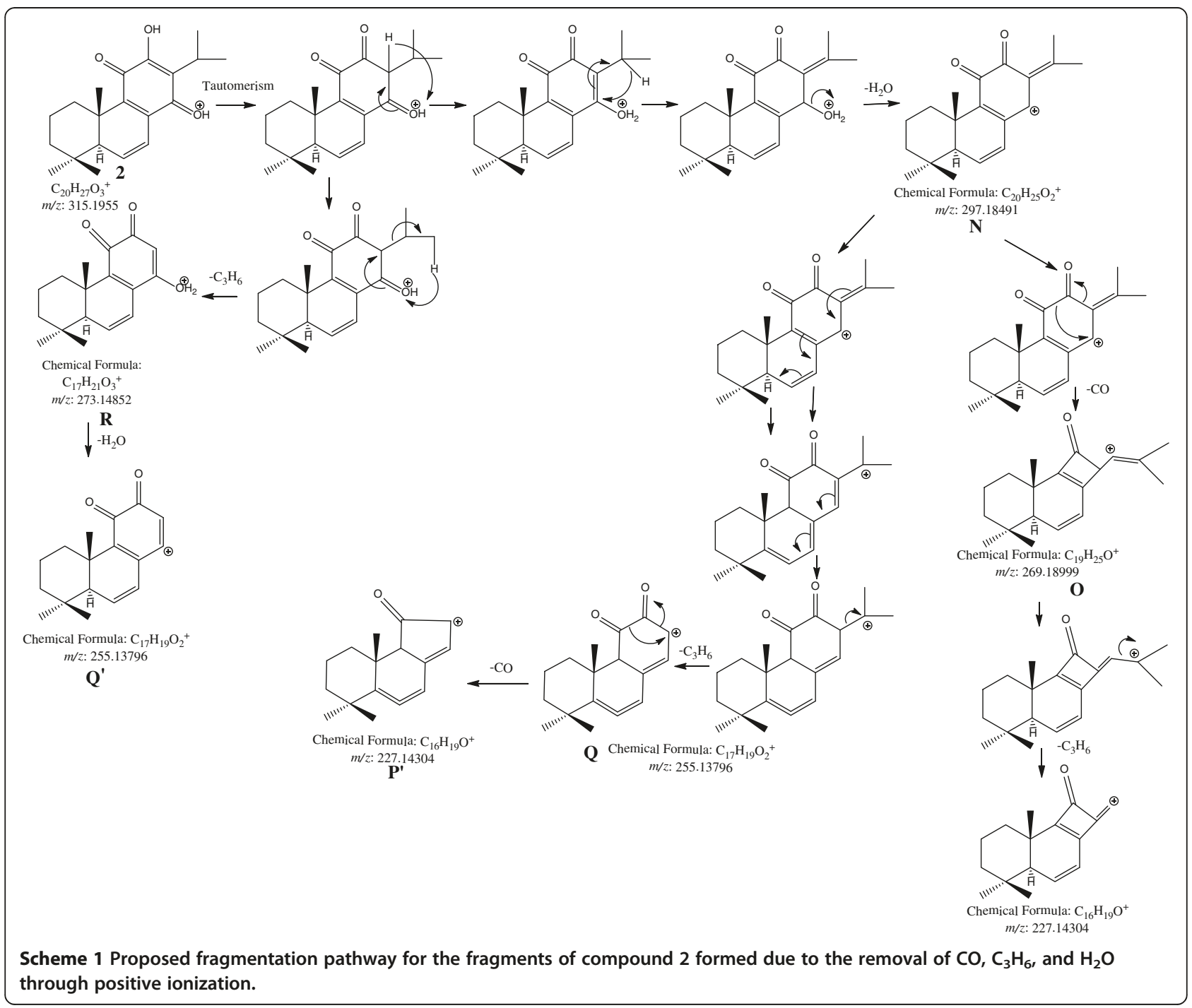


Table 2 Negative ionization HR-ESI-MS data and common neutral losses of diterpenoids 1-6

\begin{tabular}{|c|c|c|c|c|c|c|c|c|c|c|c|c|c|}
\hline S.No. & {$[\mathrm{M}-\mathrm{H}]^{-}$} & $\begin{array}{l}\text { Exact } \\
\text { Mass }\end{array}$ & $\begin{array}{c}\text { Observed } \\
\text { mass }\end{array}$ & $\begin{array}{l}\text { Error } \\
(\mathrm{ppm})\end{array}$ & {$\left[\mathrm{M}+\mathrm{H}-\mathrm{H}_{2} \mathrm{O}\right]^{-}$} & {$[\mathrm{M}+\mathrm{H}-\mathrm{CO}]^{-}$} & {$\left[\mathrm{M}+\mathrm{H}-\mathrm{CH}_{4}\right]^{-}$} & {$\left[\mathrm{M}+\mathrm{H}-\mathrm{CH}_{3}\right]^{-}$} & $\begin{array}{l}{[\mathrm{M}+\mathrm{H}-} \\
\left.\mathrm{C}_{3} \mathrm{H}_{7}\right]^{-}\end{array}$ & {$\left[\mathrm{M}+\mathrm{H}-\mathrm{C}_{3} \mathrm{H}_{7}-\mathrm{CO}^{-}\right.$} & $\begin{array}{c}\mathrm{M}+\mathrm{H}- \\
\left.\mathrm{H}_{2} \mathrm{O}-\mathrm{CO}\right]^{-}\end{array}$ & {$\left[\mathrm{M}+\mathrm{H}-\mathrm{CH}_{4}-\mathrm{CO}\right]^{-}$} & Base Peak \\
\hline 1 & $\mathrm{C}_{39} \mathrm{H}_{49} \mathrm{O}_{7}^{+}$ & 627.3327 & 627.3372 & 7.1286 & - & - & - & - & 584 & 556 & $\begin{array}{c}538 \\
{\left[\mathrm{M}+\mathrm{H}-\mathrm{C}_{3} \mathrm{H}_{7^{-}}\right.} \\
\left.\mathrm{CO}-\mathrm{H}_{2} \mathrm{O}\right]^{-}\end{array}$ & - & $\begin{array}{c}584 \\
{\left[\mathrm{M}+\mathrm{H}-\mathrm{C}_{3} \mathrm{H}_{7}\right]^{-}}\end{array}$ \\
\hline 2 & $\mathrm{C}_{20} \mathrm{H}_{27} \mathrm{O}_{3}^{+}$ & 313.1809 & 313.1789 & -6.4452 & - & 285 & 297 & 298 & - & - & - & 269 & $\begin{array}{c}285 \\
{[\mathrm{M}+\mathrm{H}-\mathrm{CO}]^{-}}\end{array}$ \\
\hline 3 & $\mathrm{C}_{20} \mathrm{H}_{27} \mathrm{O}_{5}^{+}$ & 345.1707 & 345.1694 & -3.9046 & 327 & 317 & - & - & - & - & 299 & - & $\begin{array}{c}317 \\
{[\mathrm{M}+\mathrm{H}-\mathrm{CO}]^{-}}\end{array}$ \\
\hline 4 & $\mathrm{C}_{21} \mathrm{H}_{31} \mathrm{O}_{4}^{+}$ & 345.2071 & 345.2075 & 1.0622 & $\begin{array}{c}315 \\
{\left[\mathrm{M}+\mathrm{H}-\mathrm{CH}_{2} \mathrm{O}\right]^{-}}\end{array}$ & - & - & 330 & - & - & $\begin{array}{c}287 \\
{\left[\mathrm{M}+\mathrm{H}-\mathrm{CH}_{2} \mathrm{O}-\mathrm{CO}\right]^{-}}\end{array}$ & - & \\
\hline 5 & $\mathrm{C}_{20} \mathrm{H}_{27} \mathrm{O}_{5}^{+}$ & 345.1707 & 345.1698 & -2.7458 & 327 & 317 & - & - & - & - & - & - & 179 \\
\hline 6 & $\mathrm{C}_{19} \mathrm{H}_{23} \mathrm{O}_{3}^{+}$ & 297.1496 & 297.1512 & 5.3227 & - & 269 & 281 & 282 & - & - & - & 253 & $\begin{array}{c}269 \\
{[\mathrm{M}+\mathrm{H}-\mathrm{CO}]^{-}}\end{array}$ \\
\hline
\end{tabular}


showed different fragmentation pattern due to different substituents and the presence of double bonds in the ring. These compounds showed the common losses of $\mathrm{H}_{2} \mathrm{O}, \mathrm{CO}, \mathrm{CH}_{4}$, and $\mathrm{CH}_{3}$ radical, similar to positive ion mode, except the loss of $\mathrm{CH}_{4}$, and $\mathrm{CH}_{3}$ radical Table 2 .

Compound 1, which is a dimer of two diterpenoids, showed the loss of propene radical as a base peak i.e. $\left[\mathrm{M}-\mathrm{H}-\mathrm{C}_{3} \mathrm{H}_{7}\right]^{-\cdot}$ at $\mathrm{m} / z 584.2777$ corresponding to the molecular formula $\mathrm{C}_{36} \mathrm{H}_{40} \mathrm{O}_{7}$ (calc. 584.2779). The other ions were found to be at $m / z 566\left[\mathrm{M}-\mathrm{H}-\mathrm{C}_{3} \mathrm{H}_{7}-\mathrm{H}_{2} \mathrm{O}\right]^{-}$, $556\left[\mathrm{M}-\mathrm{H}-\mathrm{C}_{3} \mathrm{H}_{7}-\mathrm{CO}\right]^{-}, 538\left[\mathrm{M}-\mathrm{H}-\mathrm{C}_{3} \mathrm{H}_{7}-\mathrm{H}_{2} \mathrm{O}-\mathrm{CO}\right]^{-}$and $528\left[\mathrm{M}-\mathrm{H}-\mathrm{C}_{3} \mathrm{H}_{7}-2 \mathrm{CO}\right]^{-}$(Figure 3B). But the lossess of methane and methyl radical were not appeared in the product ion spectra of compound $\mathbf{1}$, in comparision with other monomeric diterpenoids.

In monomeric compound 2 , the removal of $\mathrm{CO}$, i.e. [M-H-CO] $]^{-}$yielded a base peak at $m / z 285$, corresponding to the formula $\mathrm{C}_{19} \mathrm{H}_{25} \mathrm{O}_{2}$ (observed 285.1923, calc. 285.1923). The other abundant ions were $\mathrm{m} / z 297$ $\left[\mathrm{M}-\mathrm{H}-\mathrm{CH}_{4}\right]^{-}, 269\left[\mathrm{M}-\mathrm{H}-\mathrm{CH}_{4}-\mathrm{CO}\right]^{-}$and $227\left[\mathrm{M}-\mathrm{H}-\mathrm{CH}_{4}-\right.$ $\left.\mathrm{CO}-\mathrm{C}_{3} \mathrm{H}_{6}\right]^{-}$, while the minor ions at $\mathrm{m} / z 298[\mathrm{M}-\mathrm{H}-$ $\left.\mathrm{CH}_{3}\right]^{-}, 270\left[\mathrm{M}-\mathrm{H}-\mathrm{CH}_{3}-\mathrm{CO}\right]^{-}$and $148\left[\mathrm{M}-\mathrm{H}-\mathrm{CH}_{3}-\mathrm{CO}\right]^{-}$ were produced due to the loss of $\mathrm{CH}_{3}$ radical. Compounds $\mathbf{3}$ and $\mathbf{5}$, having same molecular formula, showed similar losses of $\mathrm{H}_{2} \mathrm{O}, \mathrm{CO}, \mathrm{CO}_{2}$ from the precursor ions. The ions are produced at $\mathrm{m} / \mathrm{z} 327\left[\mathrm{M}-\mathrm{H}-\mathrm{H}_{2} \mathrm{O}\right]^{-}, 301$ $\left[\mathrm{M}-\mathrm{H}-\mathrm{CO}_{2}\right]^{-}, 317$ [M-H-CO $]^{-}, 299$ [M-H-CO- $\left.\mathrm{H}_{2} \mathrm{O}\right]^{-}$and $271\left[\mathrm{M}-\mathrm{H}-2 \mathrm{CO}-\mathrm{H}_{2} \mathrm{O}\right]^{-}$. As the compound 5 have different skeleton in which the ring $\mathrm{B}$ has been modified it produce a base peak at $\mathrm{m} / z$ 179.0734 due to the fragment ion $\mathrm{C}_{10} \mathrm{H}_{11} \mathrm{O}_{3}^{-}$(calc. 179.0713), while in compound 3 the base peak was appeared at $m / z 317$ [M-H$\mathrm{CO}]^{-}$. Compound 6 yielded the base peak at $\mathrm{m} / z 269$ [M-H-CO] $]^{-}$and the other ions were found to be at $\mathrm{m} / \mathrm{z}$ $\left.281{ }^{\left[\mathrm{M}-\mathrm{H}-\mathrm{CH}_{4}\right]^{-}, 282 \text { [M-H-CH}}\right]^{-}, 253$ [M-H-CO$\left.\mathrm{CH}_{4}\right]^{-}$and 254 [M- $\left.-\mathrm{H}_{-} \mathrm{CH}_{3}-\mathrm{CO}\right]^{-}$. The product ion spectra of compound $\mathbf{1}$ in negative ionization was very simple with only a few peaks in mass range of $\geq m / z 499$. Unlike compound 1, compounds 2-6 did not show the lossess of propene and propyl radical in negative ionization. Fragmentation pathway for the fragments formed due to the removal of $\mathrm{CO}, \mathrm{CH}_{4}$, and $\mathrm{CH}_{3}$ through negative ionization has also been proposed and shown in Scheme 2 (compound 6 is taken as a representive of monomeric diterpenoids).

\section{Conclusion}

In conclusion, fragmentation pattern of six abietane-type diterpenoids and one novel dimeric conjugate diterpenoid, salvialeriafone (1) have been studied by using ESIQqTOF-MS/MS in both positive and negative ionization mode. It has been observed that many characteristic neutral losses and formation of key fragment ions can provide important structural information about the basic skeleton of abietane-type diterpenoids having dimeric linkages. The dimeric conjugate showed somewhat different pattern and less fragmentation as compared to monomeric diterpenoid analogue. The knowledge of fragmentation pattern is immensely helpful for the rapid characterization of abietane-type diterpenoids through

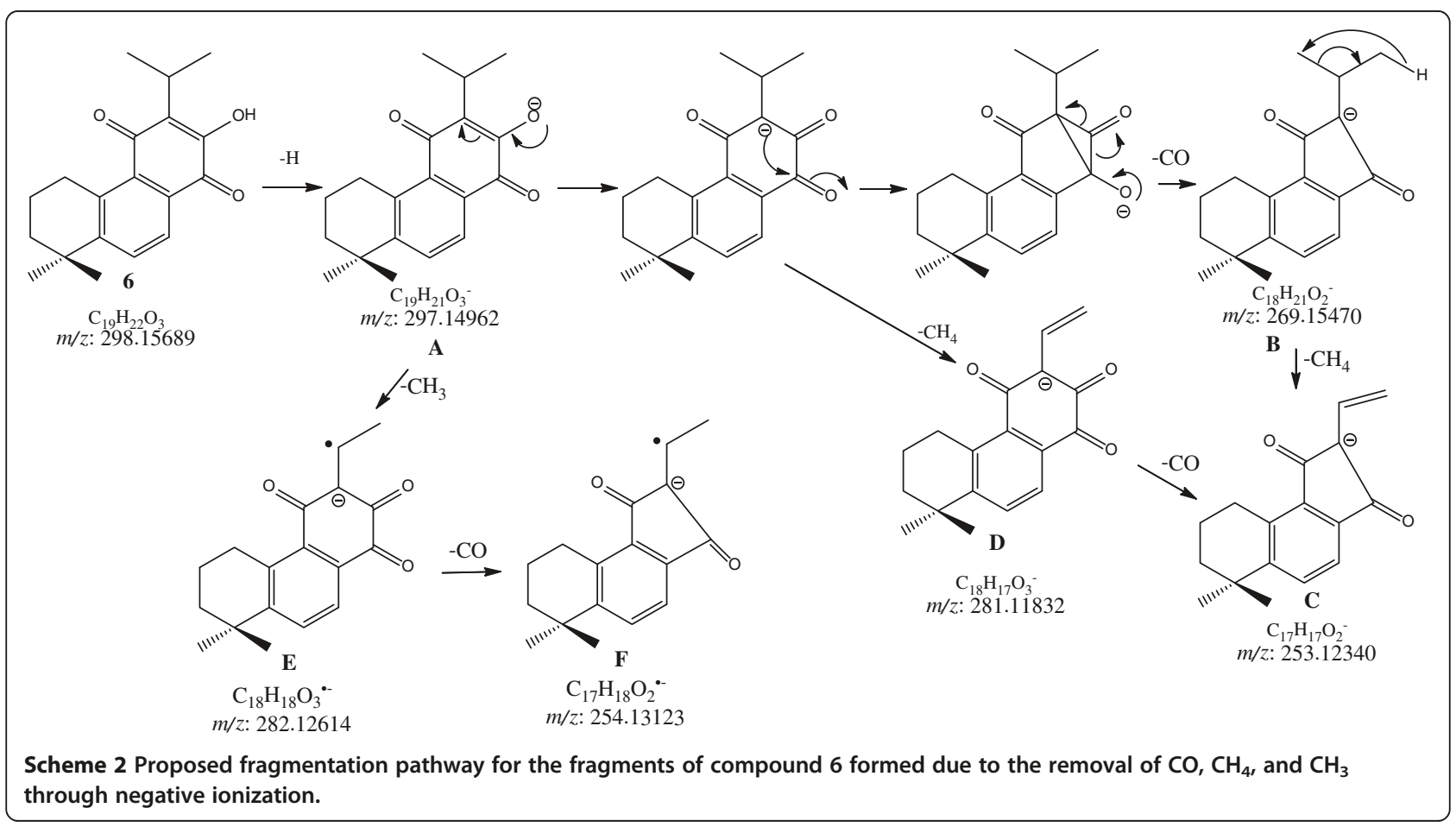


liquid chromatography coupled with mass spectrometry in complex mixtures such as plant extracts or herbal formulations by utilizing their analytical amount.

\section{Competing interests}

Authors declare that they have no competing interests.

\section{Authors' contributions}

SGM: Supervised the whole study and participated in manuscript preparation. MG: Involved in performing experimental and manuscript preparation. AH: Participated in purification of standard compounds. MIC: Involved in supervision of isolation of compounds 1-6, useful discussions and participated in manuscript preparation. All authors read and approved the final manuscript.

\section{Author details}

${ }^{1} H$.E.J. Research Institute of Chemistry, International Center for Chemical and Biological Sciences, University of Karachi, Karachi 75270, Pakistan. ${ }^{2}$ Department of Biochemistry, Faculty of Science, King Abdulaziz University, Jeddah 21412, Saudi Arabia.

Received: 31 August 2012 Accepted: 15 October 2012

Published: 18 October 2012

\section{References}

1. Caniard A, Zerbe P, Legrand S, Cohade A, Valot N, Magnard JL, Bohlmann J, Legendre L: Discovery and functional characterization of two diterpene synthases for sclareol biosynthesis in Salvia sclarea (L.) and their relevance for perfume manufacture. BMC Plant Biology. BMC Plant Biol 2012, 12:119-138

2. Devappa RK, Makkar HPS, Becker K: Jatropha toxicity: a review. J Toxicol Environ Health 2010, 13:476-507.

3. Aiyelaagbe OO, Adesogan K, Ekundayo O, Gloer JB: Antibacterial diterpenoids from Jatropha podagrica Hook. Phytochemistry 2007, 68:2420-2425

4. Sutthivaiyakit $S$, Mongkolvisut W, Ponsitipiboon P, Prabpai S, Kongsaeree $P$, Ruchirawat S, Mahidol C: A novel 8, 9-secorhamnofolane and a new rhamnofolane endoperoxide from Jatropha integerrima roots. Tetrahedron Lett 2003, 44:3637-3640.

5. Schmeda-Hirschmann G, Razmilic I, Sauvain M, Moretti C, Munoz V, Ruiz E, Balanza E, Fournet A: Antiprotozoal activity of jatrogrossidione from Jatropha grossidentata and jatrophone from Jatropha isabelli. Phytother Res 1996, 10:375-378.

6. Schmeda-Hirschmann G, Tsichritzis F, Jakupovic J: Diterpenes and a lignan from Jatropha grossidentata. Phytochemistry 1992, 31:1731-1735.

7. Jing L: Study of insecticidal active components in Jatropha curcas L. seed on its extraction, isolation and toxicity action mechanism. Sichuan University: PhD dissertation; 2005. www.fabiao.net/thread-1513285-1-1.html.

8. Jing $L$, Fang $Y$, Ying $X$, Wenxing $H$, Meng $X$, Syed MN, Fang C: Toxic impact of ingested jatropherol-I on selected enzymatic activities and the ultra structure of midgut cells in silkworm, Bombyx mori L. J Appl Entomol 2005, 129:98-104.

9. Bonito MC, Cicala C, Marcotullio MC, Maione F, Mascolo N: Biological activity of bicyclic and tricyclic diterpenoids from Salvia species of immediate pharmacological and pharmaceutical interest. Nat Prod Commun 2011, 6:1205-1215.

10. Hassan MG, Hazimi A, Miana GA: The diterpenoids of Salvia species (partll). J of chemical society of Pakistan 1994, 16:46-63.

11. Zhoua Y, Xua G, Choia FFK, Dinge LS, Hana QB, Songa JZ, Qiaoa CF, Zhaob $\mathrm{QS}$, Xua HX: Qualitative and quantitative analysis of diterpenoids in Salvia species by liquid chromatography coupled with electrospray ionization quadrupole time-of-flight tandem mass spectrometry. J Chromatogr A 2009, 1216:4847-4858.

12. Choudhary MI, Hussain A, Ali Z, Adhikari A, Sattar SA, Ayatollahi SAM, AlMajid AMA: Atta-ur-Rahman: Diterpenoids including a novel dimeric conjugate from Salvia lieriaefolia. Planta Med 2012, 78:269-275.

13. Gu M, Su ZG, Ouyang F: Fingerprinting of Salvia miltiorrhiza Bunge by Thin-Layer Chromatography Scan Compared with High Speed Countercurrent Chromatography. J Liq Chromatogr Related Technol 2006, 29:1503-1514.
14. Chang Q, Sun L, Zhao RH, Chow MSS, Zuo Z: Simultaneous determination of ten active components in traditional Chinese medicinal products containing both Gegen (Pueraria lobata) and Danshen (Salvia miltiorrhiza) by highperformance liquid chromatography. Phytochem Anal 2008, 19:368-375.

15. Wei YJ, Qi LW, Li P, Luo HW, Yi L, Sheng LH: Improved quality control method for Fufang Danshen preparations through simultaneous determination of phenolic acids, saponins and diterpenoid quinones by HPLC coupled with diode array and evaporative light scattering detector. J Pharm Biomed Anal 2007, 45:775-784.

16. Liu AH, Li L, Xu M, Lin YH, Guo HZ, Guo DA: Simultaneous quantification of six major phenolic acids in the roots of Salvia miltiorrhiza and four related traditional Chinese medicinal preparations by HPLC-DAD method. J Pharm Biomed Anal 2006, 41:48-56.

17. Cui, Wan C, Wu JL, Jiang ZH, Chan K, Cai ZW: High Performance Liquid Chromatography-mass Spectrometry Analysis for Rat Metabolism and Pharmacokinetic Studies of Lithospermic Acid B from Danshen. Talanta 2008, 75:1002-1007.

18. Li YF, Qu HB, Cheng YY: Identification of major constituents in the traditional Chinese medicine "QI-SHEN-YI-QI" dropping pill by high-performance liquid chromatography coupled with diode array detection-electrospray ionization tandem mass spectrometry. J Pharm Biomed Anal 2008, 47:407-412.

19. Liu M, Li YG, Zhang F, Yang L, Chou GX, Wang ZT, Hu ZB: Chromatography fingerprinting analysis of Danshen root (Salvia miltiorrhiza Radix et Rhizoma) and its preparations using high performance liquid chromatography with diode array detection and electrospray mass spectrometry (HPLC-DAD-ESI/MS). J Sep Sci 2007, 30:2256-2267.

20. Zhu ZY, Zhang H, Zhao L, Dong X, Li X, Chai YF, Zhang GQ: Rapid separation and identification of phenolic and diterpenoid constituents from Radix Salvia miltiorrhizae by high-performance liquid chromatography diodearray detection, electrospray ionization time-of-flight mass spectrometry and electrospray ionization quadrupole ion trap mass spectrometry. Rapid Commun Mass Spectrom 2007, 21:1855-1865.

21. Yang M, Liu AH, Guan SH, Sun JH, Xu M, Guo DA: Characterization of tanshinones in the roots of Salvia miltiorrhiza (Dan-shen) by highperformance liquid chromatography with electrospray ionization tandem mass spectrometry. Rapid Commun Mass Spectrom 2006, 20:1266-1280.

22. Musharraf SG, Ali A, Ali RA, Yousuf S, Atta-ur-Rahman, Choudhary MI: Analysis and development of structure-fragmentation relationships in withanolides using an electrospray ionization quadropole time-of-flight tandem mass spectrometry hybrid instrument. Rapid Commun Mass Spectrom 2011, 25:104-114.

23. Musharraf SG, Goher M, Ali A, Adhikari A, Choudhary Ml, Atta-ur-Rahman: Rapid characterization and identification of steroidal alkaloids in Sarcococca coriacea using liquid chromatography coupled with electrospray ionization quadropole time-of-flight mass spectrometry. Steroids 2012, 77:138-148.

24. Musharraf SG, Goher M, Wafo P, Kamdem RST: Electrospray tandem mass spectrometric analysis of duboscic acid, exploring thestructural features of a new class of triterpenoids, dubosane. Int I Mass Spectrom 2012, 310:77-80.

\section{doi:10.1186/1752-153X-6-120}

Cite this article as: Musharraf et al:: Electrospray tandem mass spectrometric analysis of a dimeric conjugate, salvialeriafone and related compounds. Chemistry Central Journal 2012 6:120. 